Turkish Online Journal of Qualitative Inquiry (TOJQI)

Volume 7, Issue 4, October 2016: 440-461

DOI: $10.17569 /$ tojqi.21319

Research Article

\title{
Infusing Global Perspectives in Social Studies Education in Turkey: Pre-service Social Studies Teachers ${ }^{1}$
}

\author{
Elvan Günel ${ }^{2}$
}

\begin{abstract}
The purpose of this study was to explore how pre-service social studies teachers understood global perspectives within social studies education and how they interpreted social studies teacher education program in terms of providing global perspectives. Phenomenological design was employed in order to gather the data. The data obtained as a result of two semistructured interviews with 11 pre-service social studies teachers and participants' journals were analyzed by using NVivo 10 package program. The data were analyzed with inductive analysis. The data were collected in the spring semester of the 2009-2010 academic year. Findings indicated that the participants' definitions or thoughts about global perspectives were shaped by their belief about globalization. The participants also stated that teaching social studies by employing global perspectives would help students to understand their own

\footnotetext{
1 This study was presented as a paper at the European Conference on Educational Research, Helsinki, 25-27 August 2010.

2 Assist.Prof.Dr., Anadolu University, Faculty of Education, Department of Social Sciences and Turkish Education, E-mail: elvang@anadolu.edu.tr
}

Received: 19.09.2016, Accepted: 30.10.2016 
Infusing Global Perspectives in Social Studies Education in Turkey: Pre-service Social Studies Teachers

prejudice and stereotypes about different cultures, ethnic and religious groups and teacher education programs are incompetent to provide such training.

Keywords: Social studies, global perspectives, global education, teacher education 


\section{Introduction}

Globalization refers to a process in which boundaries and barriers are diminished therefore connections and interactions between people are increased (Banks et. al., 2005; Kaymakçı, 2012; Scholte, 2005; Robertson, 1991). Because of globalization and new improvements in technology have resulted in increasing people's awareness of the world outside of their hometown and developing relationships and interactions between people from different cultures (Kirkwood, 2001; Cappon, 2004). Therefore cultural, ethnic, racial, and religious diversity is inevitable in our classrooms and it certainly shapes how we define education, and how and what we teach in classrooms (Alger and Harf, 1985; Apple, 2006, 2013; Banks, 2009; Hanvey, 2004; Kirkwood, 2001; Merryfield, 2002; Nieto, 2013; Pike, 2000; Ukpokodu, 1999).

Since outcomes of globalization, such as diversity being exclusively included in the classrooms, become more visible in education as well as in social and economic life, educators around the world have begun to question current educational systems and schooling in their home countries in terms of preparation of students for the challenges they might face in today's global world (Banks, 2004; Merryfield, 1998; Mundy and Manion, 2008; Kirkwood, 2002). As much as scholars in education, some educational and professional organizations such as UNESCO, UNICEF, and NCSS have pointed out that there was an increasing need to re-shape the educational policies, programs, and schools to educate students in a way that they will be ready to understand the complexities and conflicts of the ever-changing world and become informed and responsible citizens (Aç1kalın, 2010a, 2010b; Banks et. al., 2005; Günel and Öztürk, 2016; Maguth and Hilburn, 2015; Merryfield, 1998, 2002; Merryfield, 2002; Mundy and Manion, 2008; Rapoport, 2009, 2010).

At this point, scholars in countries such as Canada, United States of America, and United Kingdom, which have rapidly become diverse in terms of culture, race, ethnicity, and religion, have argued about how to educate young people to become citizens of the global world for last couple decades. They also have suggested instructional materials, programs, and courses to infuse global perspectives in education (Merryfield, 1997, 2002; Mundy and Manion, 2008). Thus global education has found its way into the social studies curricula across the world. 
Global education addresses issues such as open- mindedness, multiple perspectives, eliminating stereotyping, discrimination, racism, acceptance of diversity, different cultures, and universal values as well as different cultural values and empathy for the marginalized students (Banks, 2004; Kirkwood, 2001; Merryfield, 1998; Merryfield and Subedi, 2003). Global educators also focus on interconnectedness of the world, cross-cultural awareness, perspective consciousness, human rights, gender inequity, tolerance, social justice, respect for views of who come from different backgrounds and values of others (Hanvey, 2004; Kirkwood, 2002). In addition, global perspectives has four learning themes: Multiple perspectives, comprehension and appreciation of cultures, knowledge of global issues, and the world as an interrelated system (Kirkwood, 2001).

These new improvements in education around the world had a profound influence on educational policies in Turkey. Therefore scholars and officials from Ministry of National Education in Turkey developed a new curriculum in 2005 (MEB, 2005a, 2005b). As one of the new implementations to the social studies curriculum in Turkey, a new learning theme called "Küresel Bağlantılar " (Global Connections) was employed in the social studies curriculum from grade 4 through 7. The theme includes four units titled "Ülkemiz Ve Dünya" (Our Country And The World), "Ülkelerarası Köprüler" (Bridges Between Countries), “Uzaktaki Arkadaşlarım” (My Far Away Friends), and "Hepimizin Dünyası” (Our World) (MEB, 2005a, 2005b).

Throughout the existing literature, it has been suggested that the themes of global education are not entirely represented in the social studies curriculum in Turkey (Açıkalın, 2010a; Balkar and Özgan, 2010; Günel and Pehlivan, 2015; Kaymakç1, 2012). Researchers also pointed out that multiple perspectives as one of the themes is diminished or ignored across the curriculum and the textbooks. In addition, some researchers claimed that even though the social studies curriculum somewhat includes topics of global education, teachers are neither enthusiastic nor qualified to teach such issues in Turkey (Günel and Öztürk, 2016; Özkan, 2006). On the other hand, some studies found that in spite of having a general idea of global perspectives and appreciating positive outcomes of employing the principles of global education, teachers lacked of comprehensive knowledge and skills to implement global education into their teaching effectively (Appleyard, 2009; Mundy and Manion, 2008; Rapoport, 2010). Not surprisingly some studies stated that teacher education programs 
inadequately train pre-service teachers to teach global issues. (Alazzi, 2011; Mangram and Watson, 2011).

Research showed that teaching complex global issues effectively depends on teachers' experiences, knowledge, and critical thinking capacity (Merryfield and Kasai, 2004; DeNobile, Kleeman and Zarkos, 2014). Thus more research needs to examine how preservice teachers' beliefs, perceptions, and values are shaped and how their experiences, training, and prejudices might influence their teaching (DeNobile, Kleeman and Zarkos, 2014).

There have been a number of studies in to what extend the new improvements in education meet the needs of in-service and pre-service teachers and teacher educators in Turkey (Aykaç, 2007; Dinç ve Doğan, 2010; Doğanay, 2009; Doğanay ve Sarı, 2008; Gömleksiz, 2005); however, relatively little attention has been given to using global perspectives in social studies teacher education programs and pre-service social studies teachers' perception of global education in Turkey (Açıkalın, 2010a, 2010b; Cırık, 2008; Günel and Öztürk, 2016; Günel and Pehlivan, 2015, 2016). It is important to understand how pre-service social studies teachers perceive global perspectives within social studies education and how they interpret social studies teacher education program in terms of providing global perspectives. Hence this study aims to examine these questions:

1) How do pre-service social studies teachers perceive global perspectives within social studies education?

2) How do pre-service social studies teachers interpret social studies teacher education program in terms of providing global perspectives?

The goals of this study are particularly important because global education is a recently introduced concept in education and receives inconsiderable amount of attention within the current social studies curriculum and teacher education programs in Turkey.

\section{Research Methodology}

The purpose of this study is to understand how pre-service social studies teachers understand global perspectives within social studies education and how pre-service social studies teachers 
interpret social studies teacher education program in terms of providing global perspectives. The phenomenology design was used to conduct this study. Phenomenology aims to examine one or more individuals' views, experiences, and perceptions about a phenomenon (Creswell, 2012). As a qualitative research approach phenomenology focuses on how an individual perceives, makes sense of, and express a phenomenon (Glesne, 2012). Since this study investigates pre-service teachers' perception of global perspectives, it is important to examine participants' understandings of the phenomenon and their experiences.

\section{Participants}

The participants of the study were 11 pre-service social studies teachers who were enrolled in social studies teacher education program at a faculty of education in Turkey during the time of the study. The purposeful sampling method was employed to select participants. Thus the participants of the study were pre-service social studies teachers who were enrolled to the course titled "Global Education", which focused on issues such as globalization, contemporary concepts (i.e., prejudice, discrimination, stereotypes, democracy and democratic education, diversity etc.) and approaches, and emerging issues (i.e., war, terror, political and social conflicts etc.) around the world. The participants were selected also based on their hometown to examine to what extend cultural differences would influence their perception. The participation was on a voluntary basis. Profiles of the participants were presented in Table 1.

Table 1

Profiles of the Participants

\begin{tabular}{lcll}
\hline Participants & Age & Sex & Hometown \\
\hline Aliye & 22 & Female & Uşak \\
Didem & 20 & Female & Zonguldak \\
Esra & 22 & Female & Samsun \\
Hakan & 24 & Male & Kahramanmaraş \\
Öznur & 20 & Female & Afyon \\
Şevket & 23 & Male & Bingöl \\
Şeyda & 21 & Female & Bartın \\
Serkan & 22 & Male & Kirklareli \\
Servet & 29 & Male & Manisa \\
Selçuk & 22 & Male & Batman \\
Tarık & 21 & Male & Ardahan \\
\hline
\end{tabular}




\section{Data Collection and Analysis}

In phenomenological studies, interviews are the main data collection tools because they can be used to understand and define an individual's experiences and thoughts on a phenomenon (Creswell, 2012; Glesne, 2012). In the study, two 30-minute individual and semi-structured interviews conducted to obtain further information about the questions of the study such as how the participants defined global perspectives. The interview questions were prepared under three categories from general to the more detailed questions: Background information of the participants such as age, hometown, environment they live in and their definitions of global perspectives, global education, and globalization; detailed questions regarding the participants' experiences inside and outside of the class, and how they perceive global perspectives and global education within social studies education in terms of the social studies curriculum and teacher education programs; questions to gain insight into how well they think global perspectives and global education fit into the Turkish educational system.

In addition to the interviews, the researcher also asked the participants to keep a journal during the time of the study and the course. The journals focused on how the participants felt during the in-class activities (including mid-term exam and final assignment) and what their thoughts were about in-class and online discussions on controversial issues. Table 2 presents the assignments of the "Global Education" course.

\section{Table 2}

Assignments of the "Global Education" Course

\begin{tabular}{ll}
\hline Assignments & Duration \\
\hline Read a newspaper and interpret pictures & Approximately 60 minutes \\
Re-writing a story & Approximately 60 minutes \\
Preparing a concept map & Approximately 60 minutes \\
Lectures about global/international issues & Approximately 30 minutes per class \\
In-class discussions/current events & Approximately 25 minutes per class \\
Online discussions/current events & 13 weeks \\
Interaction with students from various ethnic & 13 weeks \\
groups & \\
Reading research articles/multicultural and & 13 weeks \\
global education & \\
Preparing a lesson plan & Approximately 60 minutes \\
Watching/examining movies & 2 weeks \\
\hline
\end{tabular}


While conducting interviews, it is important to build a trustworthy relationship between the researcher and the participants so they can freely express their thoughts and feelings about the phenomenon (Glesne, 2012). In this study, since the researcher was also the instructor of the "Global Education" course that the participants were enrolled during the time of the study, second interviews were conducted after the students completed the course. Oral and written consent of the participants were also taken to gather data in the study. The written consent forms included that all the participants was going to be informed how the data was going to be gathered, used, and that she/he did not have to answer questions that she/he found uncomfortable. The researcher also made sure to provide privacy and confidentiality; therefore the participants were given pseudonyms during the study. The participants was also informed by the researcher that they were free to withdraw from participation at any time during the study and their decision to withdraw from the study was not going affect their grades. The data obtained as a result of the interviews and participants' journals were analyzed through in NVivo 10 package program. Since there were no structured themes, inductive analysis approach was used. First, codes then based on these codes, themes were found by coding the data line by line. After completing the first line-by-line coding, total 30 nodes were found. Then these nodes were reduced to four main themes and at the end of indepth the analysis, three major findings were emerged. In order to improve the trustworthiness of the study, the researcher conducted face-to-face member check with all the participants and employed multiple methods (i.e., multiple individual interviews with the participants and participants' journals) to collect data.

\section{Findings}

The findings of the study emerged under three main categories; 1) Pre-service social studies teachers' understanding of global perspectives in social studies education, 2) Pre-service social studies teachers' ideas about the importance of infusing global perspectives in social studies education in Turkey, 3) Pre-service social studies teachers' understanding of different cultures and their ideas on their own proficiency in teaching about sensitivity to differences and awareness of different cultures, people, multicultural, ethnic, and religious influences. 


\section{Participants' Definitions of Global Perspectives}

Findings of the study indicated that the participants' definitions or thoughts about global perspectives were based on their beliefs about globalization and associated with such concepts as exploitation, imperialism, and liberalism. In addition, a majority of pre-service social studies teachers stated that they have not heard or learned about global perspectives. Therefore they either could not define global perspectives at all or defined it incorrectly. According to participants' responses, there are two main factors that contributed to the participants' lack of knowledge and disinformation. These factors included not being able to learn about global perspectives in school during their education (i.e., primary school through college) in Turkey and learning about it in informal ways such as through the Internet, media, and uninformed peers. For example Aliye said that, 'it is going to be a little difficult for me to define global perspectives. I can only guess and as far as I know it is something regarding globalization, imperialism, and liberalism. ' Selçuk and Servet stated that, 'I don't know about global perspectives at all.' Findings showed that participants' lack of knowledge about global perspectives led to major misconceptions about what global perspectives actually means. Some participants associated global perspectives with globalization. Thus, they simply described the term as "something related to globalization." Aliye added, 'I do not know for sure, if I have to guess, it is to create homogenous world and homogenous culture.'

Furthermore, when participants were asked to define global perspectives, some participants defined it as an 'educational system, which would make all people become identical to each other and cause loss of individuality so people would speak a common language and share the same religious beliefs all around the world.' Other participants stated that, 'since globalization is becoming more important everyday around the world, it seems to me global education means everyone receiving the same education all around the world...For example, education in Turkey is getting equal to an education in Europe or in the United States.' Hakan stated that, 'thinking about global education, first I can say that it is about globalization and education. An education that is planned to improve human behavior and it is universal. It can be employed in Turkey and at the same time in Europe.'

On the other hand, Serkan added; 
"Technology has developed all around the world. For example, I have been in this university for couple of years and things change very fast. Perceptions for example change. Educational policies change. There are new improvements in education, new methods. I believe this forces people to learn about the world. Global education is important; for example, I might receive the very same education I am getting right now from the United States. I mean equality. Equal right to access to the same education all around the world."

In addition Şeyda explained;

"In fact, I am just beginning to learn about global perspectives. That is why I am mostly curious about globalization. To me globalization is spreading some ideas and perspectives to all around the world. In this case global education is a development in education based on new improvements on technology, science, and communication around the world."

In addition, Elif and Tar1k explained that global perspectives are about 'globalization of the world and relationships and interactions among people who have different cultural backgrounds.' Findings of the study also showed that all the participants in the study stated that after completing the assignments of the "Global Education" course their understanding of global perspectives shifted from "unclear" and "harmful" to "necessary" and "helpful."

\section{Importance of Infusing Global Perspectives in Social Studies Education in Turkey}

All the participants in the study suggested that infusing global perspectives in social studies education in Turkey is crucial since Turkey has racially, culturally, ethnically, and religiously diverse social structure. Participants also pointed out that during the course they had a better understanding of their own prejudice and stereotypes about different cultures and ethnic groups so they have come to believe that global education might help eliminating stereotypes and discrimination. Tarık explained;

\footnotetext{
"I realized that we already have stereotypes against different cultures in our own society let alone about other cultures around the world and people from different countries might have prejudice about Turkish culture too. Global education might help eliminate or diminish stereotypes about different cultures. I would try to do the same thing as a social studies teacher."
}

In addition Hakan, Şeyda, Esra, and Didem strongly emphasized that the "Global Education" course ought to be offered in not only social studies teacher education program but also all 
teacher education programs in Turkey. Hakan explained;

"All teacher education departments must offer a global education course because it is about relationships and interactions among people and different worldviews. College is where students re-describe themselves and re-shape their worldviews. It also should be offered in secondary education as well. I mean in the curriculum as a separate course so that students might learn about concepts such as prejudice, discrimination, tolerance, and stereotypes at an early age."

Esra stated that global perspectives might help social studies teachers to be more critical when they teach about history, which is a significant part of the social studies curriculum in Turkey. Esra also claimed that the "Global Education" course enabled her to explore her own ethnocentric views therefore it may help social studies teachers to examine and discuss their own ethnocentric views and issues of race and class in Turkey as well as the world. She further explained;

"First of all, I believe we teach history but we do not know our own history...our understanding of history is about only our national flag and saying hey "we are the Turks"...but we need to think and discuss these issues. I mean it is good that we love our flag and nation but if we perceive our nationality higher than other nationalities around the world, it is inappropriate."

Similar to Esra, Öznur, Selçuk, and Şevket emphasized that infusing global perspectives into social studies courses and the curriculum would help students to be familiar with different cultures and be aware of their own prejudices.

\section{Participants' Understanding of Different Cultures}

The findings of the study also showed that pre-service social studies teachers' knowledge about different cultures comes from non-formal education and they found themselves inadequate in terms of being sensitive to differences and being aware of different cultures, people, and recognizing multicultural, ethnic, and religious influences as social studies teacher candidates. All the participants emphasized that their knowledge about different cultures mostly comes from media, social media, and their peers rather than from schools. They stated that the only time they have learned and discussed about different cultures inclass during their education was in this "Global Education" course. 
While Şevket pointed out that he learned from different cultures from his own by watching TV and documentaries, Serkan, Şeyda, and Didem stated that they met with people who have different backgrounds while socializing in college and this is how they mostly have learned about different cultures. In addition, Serkan explained that only after completing the "Global Education" course, he realized that even though Turkey is a multicultural society in terms of religion, ethnicity, race, and political views, people including himself "somehow prefer spending time with people who have similar cultural beliefs and worldviews rather than people from different cultures."

In this study, even tough participants often used "different culture" as a term when they described their relationship with their ethnically and religiously different peers during the interviews, when they were asked to define different culture as a concept; all the participants except Serkan described different culture as cultural beliefs that are different from their own and exist outside of geographical borders of Turkey. None of them focused on ethnic, cultural, and religious differences even though they referred to different ethno-cultural groups in Turkey during interviews.

Şevket stated;

\begin{abstract}
"Different culture means a cultural beliefs that are different from ours...for example I don't see any differences between Turkish and Kurdish culture...maybe geographical differences like in the East people are a bit tough...we have more strict rules compared to the West...different cultures, they are outside of Turkey. I believe they are more flexible as far as I know from the documentaries."
\end{abstract}

Didem also explained that, "when you ask how I define different culture, I can describe it as everything that is different such as different food, clothes, and language...I consider everyone in Turkey including myself as Turkish even though I am from the Black Sea Region and I have a different ethnic background."

The participants also stated that they have learned about concepts such as discrimination, prejudice, racism, and diversity thoroughly for the first time in their educational life during the course and they believed in "finding a common ground" when it comes to in-class discussions about cultural differences. 
Pre-service social studies found themselves inadequate in terms of being sensitive to differences and being aware of different cultures, people, and recognizing multicultural, ethnic, and religious influences. Şevket pointed out that "if we were to infuse global perspectives into social studies courses and the curriculum thoroughly, it would be a bit difficult to find teachers who are eligible to teach these issues in Turkey...more teachers need to be educated and one elective course in the social studies teacher education program is not enough." Moreover all the participants pointed out that although they believed infusing global perspectives into their teaching is important to educate students to become informed and responsible citizens and deal with the challenges they might face in a global world, they stated that they lacked of proficiency in teaching about sensitivity to differences and awareness of different culture, people, multicultural, ethnic, and religious influences.

\section{Discussion, Conclusion, and Implications}

In the last decade, nation-states throughout the world had to welcome growing diversity and increasing recognition of diversity due to immigration of many people who were pursuing better economic, social, and political opportunities to live more comfortable lives. Therefore countries such as United States of America, Canada, France, and Germany experienced immigration and its outcomes. Increased diversity and its recognition led educators in such countries to reexamine educational policies since culturally, religiously, and ethnically diverse societies are faced with the challenge of infusing mutual values, standards, and objectives to which all citizens are committed regardless of their race, ethnicity, religion, and status (Banks et. al., 2005; Kılınç and Korkmaz, 2015; Maguth and Hilburn, 2015; Mundy and Manion, 2008; Rapoport, 2009, 2010).

Even though nation-states which have been culturally, religiously, and ethnically diverse since their foundation such as Turkey were used to deal with immigration and its consequences, they had political and social conflicts over changes in ethnic composition. Hence balancing unity and diversity has become a big challenge for countries such as Turkey (Atasoy, 2005). In order to overcome this challenge by implementing new educational policies, Ministry of National Education of Turkey developed a new curriculum and included global perspectives into the social studies education (MEB, 2005a, 2005b). 
In the study, it was found that the participants' definitions or thoughts about global perspectives were shaped by their belief about globalization and associated with such concepts as exploitation, imperialism, and liberalism. Thus they stated that what global perspectives/global education actually means is "unclear" and integrating global perspectives into social studies courses and the curriculum might be "harmful" and considered as unpatriotic. Similar to the findings of this study, Cirık (2008), in his research focused on multicultural education approach and its reflections and Cushner (1998) claimed that multicultural education is a highly misunderstood and feared concept by educators and students. This fear might come from the belief that employing multicultural education approach might destroy social cohesion and national unity. Hence it might be considered as unpatriotic movement easily. Günel and Öztürk (2016) also found that social studies teachers in Turkey had negative attitudes towards global education since they associated global education with globalization, which would mean social, political, and economic conflicts around the world. In addition, Günel and Pehlivan (2016) investigated social studies preservice teachers' perception of global citizenship and global citizenship education, which addresses issues such as human rights, social justice, and environmental problems. It also aims to develop global skills similar to global education. They found that the participants did not consider themselves as global citizens because they believed that one of requirements to be a global citizen was being free of national feelings. However, Göl (2013) and Richardson, Blades, Kumano and Karaki (2003) found that pre-service social studies teachers especially in Canada and Japan had positive attitudes towards global citizenship. Atasoy (2005) also pointed out fear of losing national unity due to globalization and employing global education and claimed that rise of globalization would never cause loss of nationalism. Moreover one would be a global citizen without losing his/her national feelings (Günel and Pehlivan, 2016; Kılınç and Korkmaz, 2015).

The participants of this study stated that after completing the assignments of the "Global Education" course, their perception of global perspectives/global education have changed from "unclear" and "harmful" to "necessary" and "helpful." Similar to this finding, Günel and Pehlivan (2016) found that some elective courses such as global education, values education, and effective citizenship education in some social studies teacher education programs in Turkey affected students' perception of global citizenship positively. 
Another finding of the study regarded pre-service social studies teachers' ideas about the importance of implementing global perspectives in social studies education. The participants claimed that as they experienced in the "Global Education" course, teaching social studies by employing global perspectives would help students to understand their own prejudice and stereotypes about different cultures, ethnic and religious groups. Thus it would improve their worldviews as well as their understandings of social and political events that affect the world and eventually help them to become open-minded and informed citizens. They also said that they would be more critical when they teach about history. However, the participants emphasized that the social studies curriculum and social studies teacher education programs in Turkey lacked providing students with such skills. Likewise, Açıalın (2010a, 2010b), Günel and Pehlivan (2015), and Günel and Pehlivan (2016) revealed that the social studies curriculum, eighth grade citizenship and democracy education curriculum, the textbook, and social studies teacher education programs in Turkey are found to have shortcomings in terms of the skills and values global and multicultural education aim to teach. Moreover Ersoy (2013) claimed that teachers were incompetent and unenthusiastic about teaching their students how to solve real-life problems, use multiple perspectives inside and outside of classroom, and be more open-minded and empathetic in Turkey.

The participants also explained that they have learned about different cultures through media, social media, and their peers. They added that the only time they have learned about different cultures exist both within and outside of Turkey in-class was during the "Global Education" course. Similarly, Günel and Pehlivan (2016) found that pre-service social studies teachers learn about global citizenship and related concepts via peers, social media, and nongovernmental organizations rather than in-class. They also stated that it was somewhat mentioned only in two elective courses; global education and effective citizenship education. Findings of these two studies emphasize that teacher education programs in Turkey lack of providing students with opportunities to learn about complex global issues.

The participants defined different culture as "cultural beliefs, food, clothes, and language different from their own." They added that what they mean by different culture is that cultural beliefs and worldviews different from their own and exist outside of Turkey. Modern Turkey with the legacy of Ottoman Empire is "multi-ethnic and multi-cultural country, housing approximately 50 different Muslim and/or non-Muslim ethno-cultural groups: Sunni Turks, Alevi Turks, Sunni Kurds, Alevi Kurds, Circassians, Lazis, Armenians, Georgians; Jews, 
Greeks, Arabs etc.” (Kaya and Harmanyeri, 2010, p. 4). The participants of this study emphasized that these ethno-cultural groups cannot be categorized as "different culture" but can be considered as "cultural differences" within Turkish culture. Based on the participants' definitions of different culture, it can be said that offering one course in teacher education programs is not enough for pre-service teachers to develop deeper understanding complex global issues such as culture. Thus teacher education programs need to improve students' learning experiences so that they can have a better understanding of complex global issues.

All the participants strongly emphasized that even though they believed infusing global perspectives into social studies classrooms and the curriculum is significant especially while teaching history, democracy, and human rights, they found themselves inadequate to teach about sensitivity to differences and awareness of different culture, people, multicultural, ethnic, and religious influences. They claimed that not only social studies teacher education programs but also all teacher education programs should offer courses, which would help them, develop intercultural competence. Similar to the finding of this study, Ceylan (2014), Ersoy (2013), Günel and Öztürk (2016), Günel and Pehlivan (2016), Rapoport (2010), and Smith (2009) found that both in-service and pre-service social studies teachers had difficulties while teaching their students various skills such as using multiple perspectives in-class discussions, being more open-minded about differences, problem solving, and critical thinking.

Based on the findings of the study, several useful implications can be suggested: Integrating global perspectives into social studies courses and the curriculum in Turkey should be a priority for educators. Social studies teacher education programs should offer courses both elective and mandatory to teach pre-service teachers to develop skills such as being openminded and empathetic to differences, critical thinking, problem solving, using multicultural perspective while teaching current events and controversial issues. Current courses that are offered in social studies teacher education programs ought to be redesigned in a way that they would improve students' understanding of others and help them to learn how to teach global issues by employing different technologies, strategies, and instructional methods. Moreover further studies that employ different methods such as action research should be conducted to improve pre-service teachers' knowledge and skills on global education and examine developments and changes in teacher education programs. 


\section{References}

Açıkalın, M. (2010a). Influence of global education on the Turkish social studies curriculum. The Social Studies, 101(6), 254-259. Doi. 10.1080/00377991003774887.

Açıkalın, M. (2010b). New approaches for teaching social studies: Multicultural and global education. Elementary Education Online, 9(3). 1226-1237. Retrieved from http://ilkogretim-online.org.tr/ vol9say3/v9s3m31.

Alazzi, K. (2011). Teachers perceptions and conceptions of global education: A study of Jordanian secondary of social studies teachers. The Journals of Multiculturalism in Education, 7(1), 1-19.

Alger, C.F, \& Harf, J.E. (1985). Global education: Why? For whom? About what?. American Association of Colleges for Teacher Education, Washington D.C. Retrieved from http://eric.ed.gov/?id=ED265107.

Anderson, C.C. (1982). Global education in the classroom. Theory into Practice, 21(3), 168176.

Apple, M.W. (2013). Can education change society?. New York and London: Routledge.

Appleyard, N. (2009). Teacher and student perceptions of the goals of global education. (Unpublished master thesis), Faculty of Education/University of Ottawa, Ottawa.

Atasoy, F. (2005). Küreselleşme ve milliyetçilik. Ankara: Ötüken.

Apple, M.W. (2006). Understanding and interrupting neoliberalism and neoconservatism in education. Pedagogies: An International Journal. 1(1), 21-26. Doi. 10.1207/ s15544818 ped0101_4.

Aykaç, N. (2007). İlköğretim sosyal bilgiler dersi eğitim-öğretim programina yönelik öğretmen görüşleri. Elektronik Sosyal Bilimler Dergisi, 6(22), 46-73, Retrieved from http://www.e-sosder.com.

Banks, J.A. (2004). Introduction: Democratic citizenship education in multicultural societies. in Diversity and citizenship education: Global perspectives. (J. A. Banks Ed.), San Francisco: Jossey-Bass, An Imprint of Wiley. 
Banks, J.A., Banks, C.A., Cortes, C., Hahn, C., Merryfield, M., Moodley, K., \& Parker W. (2005). Democracy and diversity: Principles and concepts for educating citizens in a global age. Center for Multicultural Education, University of Washington: Seattle.

Banks, J.A. (2009). The Routledge international companion to multicultural education. New York: Routledge.

Cappon, P. (2004). Social implications of globalization: Can new ways of learning humanize our global institutions? Retrieved from http://www.21learn.org/archive/socialimplications-of-globalization-can-new-ways-of-learning-humanize-our-globalinstitutions/.

Ceylan, Ş. (2014). Okul öncesi öğretmenlerinin dünya vatandaşlığı eğitimi ile ilgili görüşleri. Kuramsal Eğitimbilim Dergisi, 7(1), 78-93.

Cırık, İ. (2008). Çokkültürlü eğitim ve yansımaları. Hacettepe Üniversitesi Eğitim Fakültesi Dergisi, 34, 27-40.

Creswell, J.W. (2012). Educational research: Planning, conducting, and evaluating quantitative and qualitative research. Retrieved from basu.nahad.ir/uploads/creswell.pdf.

Cushner, K. (1998). International perspectives on intercultural education. New York: Lawrence Erlbaum Associates.

Dinç, E., \& Doğan, Y. (2010). İlköğretim ikinci kademe sosyal bilgiler öğretim programı ve uygulanması hakkında öğretmen görüşleri. Sosyal Bilgiler Eğitimi Araştırmaları Dergisi, 1(1), 17-49.

DeNobile, J., Kleeman, G., \& Zarkos, A. (2014). Investigating the impacts of Global Education curriculum on the values and attitudes of secondary students. Geographical Education, 27, 28-38.

Doğanay, A. (2009). Çağdaş sosyal bilgiler anlayışı 1şı̆̆ında yeni sosyal bilgiler programının değerlendirilmesi. Ç.Ü. Sosyal Bilimler Enstitüsü Dergisi, 17(2), 77- 96.

Doğanay, A., \& Sarı, M. (2008). Öğretmen gözüyle yeni sosyal bilgiler programı: Adana ilinde bir araştırma. Ilköğretim Online. 7(2), 468-484. Retrieved from http://ilkogretimonline.org.tr. 
Gömleksiz, M.N. (2005). Yeni ilköğretim programının uygulamadaki etkililiğinin değerlendirilmesi. Kuram ve Uygulamada Eğitim Bilimleri, 5(2), 371-384.

Ersoy, A.F. (2013). Sosyal bilgiler dersinde küresel vatandaşlık eğitimi: Uluslararası çatışma ve savaşlara ilişsin Türk öğretmen ve öğrencilerin deneyimleri. Eğitimde Nitel Araştırmalar Dergisi, 1(1), 7-30.

Glesne, C. (2012). Nitel Araştırmaya Giriş. (Ali. Ersoy and P. Yalçınoğlu, Trans.). Ankara: An1.

Göl, E. (2013) Sosyal bilgiler öğretmen adaylarının küresel vatandaşlık tutum düzeylerinin farklı değişkenler açısından incelenmesi. (Unpublished master thesiszi). Graduate School of Social Sciences, Ahi Evran University, Kırşehir.

Öztürk, F., \& Günel, E. (2016). Sosyal bilgiler öğretmenlerinin küresel sistem, küresel eğitim ve çeşitlilik kavramlarına ilişkin algısı. İlköğretim Online, 15(1), 172-185. Doi: http://dx.doi.org/10.17051/io.2016.79798.

Günel, E. \& Pehlivan, A. (2015). Examining the citizenship and democracy education textbook and curriculum in terms of global education. Journal of Social Studies Education Research, 6(1), 123-171.

Günel, E., \& Pehlivan, A. (2016). Pre-service social studies teachers' perception of global citizenship. Journal of Education and Future, 10, 51-69.

Hanvey, R.G. (2004). An attainable global perspective. The American Forum for Global Education, 2-47. Retrieved from http://www.globaled.org/an_att_glob_persp_04_11_29.pdf.

Kaya, A. \& Harmanyeri, E. (2010). Tolerance and cultural diversity discourses in Turkey. European Institute, İstanbul Bilgi University, İstanbul.

Kaymakçı, S. (2012). Global education in the Turkish social studies teacher training programme. Croation Journal of Education, 14(4), 817-854. Retrieved from http://hrcak. srce.hr/94325.

Kılınç, E., \& Korkmaz, U. (2015). From national to global citizenship Turkish perspectives on the meaning of global citizenship. In M. Merryfield, T. Augustine, \& J. Harshman 
(Eds.), Research in Global Citizenship Education (pp. 163-188). Charlotte, NC: Information Age Publishing.

Kirkwood. T.F. (2001). Our global age requires global education: Clarifying definitional ambiguities. The Social Studies. 92(1), 10-15. Doi: 10.1080/00377 990109603969.

Kirkwood, T.F. (2002). Jamaican students of color in the American classroom: Problems and possibilities in education. Intercultural Education. 13(3), 305313.

Lakes, R.D., \& Carter, P.A. (2011). Neoliberalism and education: An introduction. Educational Studies: A Journal of the American Educational Studies Association, 47(2), 107-110.

Maguth, B., \& Hilburn, J. (2015). The state of global education: Learning with the world and its people. New York and London: Routledge.

Mangram, J., \& Watson, A. (2011). Us and them: social studies teachers' talk about global education. Journal of Social Studies Research, 35(1), 95-116.

MEB. (2005a). İlkögretim sosyal bilgiler dersi 4-5. sınıflar ögretim programı. (Primary school 4th and 5th grades social studies curriculum guide). Ankara: MEB.

MEB. (2005b). İlköğretim sosyal bilgiler dersi 6-7. sınıflar ögretim programı ve kılavuzu. (Primary school 6th and 7th grades social studies curriculum guide). Ankara: MEB.

Merryfield, M.M. (1993). Reflective practice in global education: Strategies for teacher educators. Theory Into Practice, 32(1), 27-32.

Merryfield, M.M. (1997). A framework for teacher education in global perspectives. In M. Merryfield, E. Jarchow \& S Pickert (Eds.), Preparing teachers to teach global perspectives: A handbook for teacher educators (pp.1-24). Thousand Oaks, CA: Corwin Press.

Merryfield, M.M. (1998). Pedagogy for global perspectives in education: Studies of teachers' thinking and practice. Theory and Research in Social Education, 26(3), 342-379.

Merryfield, M.M. (2002). The difference a global educator can make. Educational Leadership, 60(2), 18-21. 
Merryfield, M.M., \& Kasai, M. (2004). How are teachers responding to globalization? (Research and practice). Social Education, 68(5), 354-356.

Merryfield, M.M., \& Subedi, B. (2003). A global education framework for teaching about the World's women. Social Education, 67(1), 10-16.

Mundy, K., \& Manion, C. (2008). Global education in Canadian elementary schools: An exploratory study. Canadian Journal of Education. 31(4), 941-974. Retrieved from http://eric.ed.gov/?id=EJ830510.

Nieto, S. (2013). Diversity, Globalization, and Education: What Do They Mean for Teachers and Teacher Educators?. Kappa Delta Pi Record, 49(3), 105-107. Doi: $10.1080 / 00228958.2013 .819183$.

Özkan, T. (2006). İlköğretim Öğretmenlerinin Küresel Eğitime Yönelik Görüşlerinin Değerlendirilmesi. (Unpublished master thesis). Graduate School of Social Sciences, Çukurova University, Adana.

Pike, G. (2000). Global education and national identity: In pursuit of meaning. Theory into Practice, 39(2), 64-73.

Rapoport, A. (2009). A forgotten concept: Global citizenship education and state social studies standards. Journal of Social Studies Research, 33(1), 91-112.

Rapoport, A. (2010). We cannot teach what we don't know: Indiana teachers talk about global citizenship education. Education, Citizenship and Social Justice, 5(3), 179-190.

Richardson, G., Blades, D., Kumano, Y., \& Karaki, K. (2003). Fostering a global imaginary: The possibilities and paradoxes of Japanese and Canadian students' perceptions of the responsibilities of world citizenship. Policy Futures in Education, 1(2), 402-420.

Robertson, R. (1991). The globalization paradigm: Thinking globally. In Religion and Social Order (pp. 207-224). Greenwich: JAI Press.

Scholte, J.A. (2005). The sources of neoliberal globalization. United Nations Research Institute for Social Development (UNRISD). Retrieved from http://unrisd.org/UNRISD/website/document.nsf/ab82a6805797760f80256b4f005da1ab /9e1c54ceeb19a314c12570b4004d0881/\$FILE/scholte.pdf. 
Infusing Global Perspectives in Social Studies Education in Turkey: Pre-service Social Studies Teachers

Smith, E.B. (2009). Approaches to multicultural education in preservice teacher education: Philosophical Frameworks and models for teaching. Multicultural Education, 16(3), 4550 .

Ukpokodu, N. (1999). Multiculturalism vs. globalism. Social Education, 63(5), 298-300. Retrieved from http://eric.ed.gov/?id=EJ612181. 